\title{
Evaluasi Anggaran Biaya Produksi pada PT. Perkebunan Nusantara III Di Kota Medan
}

\section{Evaluation of Budget on Production Costs PT. Perkebunan Nusantara III In Medan City}

\author{
Sinta Kismi Hana*, Beby Mashito Batubara \& Nina Angelia \\ Program Studi Administrasi Publik, Fakultas Ilmu Sosial Dan Ilmu Politik, \\ Universitas Medan Area, Indonesia \\ Abstrak
}

\begin{abstract}
Tujuan penelitian mengenai yaitu untuk mengevaluasi anggaran biaya produksi pada PT. Perkebunan Nusantara III Penelitian ini merupakan penelitian yang menggunakan pendekatan kualitatif dengan metode deskriptif yang dimaksud adalah dengan menggunakan keterangan data yang didapat pada saat penelitian dan dari lapangan berupa data yang secara tertulis maupun lisan dari pihak-pihak yang terlibat. Hasil yang diperoleh bahwa PT. Perkebunan Nusantara III telah mengevaluasi perhitungan biaya produksi secara periodik, berdasarkan dengan laporan berdasarkan harga produksi, harga jual, dan rugi laba dengan menentukan biaya panen, biaya pemeliharaan, biaya overhead pabrik, biaya penggolahan, dan biaya penyusutan. anggaran yang disusun oleh PT. Perkebunan Nusantara III belum cukup sempurna dikarenakan masih banyaknya terjadi penyimpangan yang signifikan baik penyimpangan yang mengguntungkan maupun yang merugikan. Hal ini menjadi tanggung jawab manajer agar melakukan evaluasi lebih mendalam membuat realisasi biaya agar tidak terjadinya penyimpangan terlalu jauh. Kesimpulan melalui penelitian dilapangan bahwa PT. Perkebunan Nusantara III telah membuat anggaran biaya produksi dengan periode pertahunnya. PT. Perkebunan Nusantara III telah mengevaluasi perhitungan biaya produksi secara periodik, berdasarkan dengan laporan berdasarkan harga produksi, harga jual, dan rugi laba dengan menentukan biaya panen, biaya pemeliharaan, biaya overhead pabrik, biaya penggolahan, dan biaya penyusutan. Anggaran yang disusun oleh PT. Perkebunan Nusantara III belum cukup sempurna.

Kata Kunci: Evaluasi, Anggaran Biaya, Produksi
\end{abstract}

\begin{abstract}
The purpose of this research is to evaluate the production cost budget at PT. Perkebunan Nusantara III This research is a study that uses a qualitative approach with a descriptive method in question is to use information data obtained at the time of the study and from the field in the form of data that is written or oral from the parties involved. The results obtained that PT. Perkebunan Nusantara III has evaluated the calculation of production costs periodically, based on reports based on production prices, selling prices and profit and loss by determining harvest costs, maintenance costs, factory overhead costs, processing costs, and depreciation costs. budget prepared by PT. Perkebunan Nusantara III is not yet perfect enough because there are still many significant deviations both beneficial and adverse. This is the responsibility of managers to conduct more in-depth evaluations to make the realization of costs so as not to occur too far away. Conclusions through field research that PT. Perkebunan Nusantara III has made a production cost budget with a yearly period. PT. Perkebunan Nusantara III has evaluated the calculation of production costs periodically, based on reports based on production prices, selling prices and profit and loss by determining harvest costs, maintenance costs, factory overhead costs, processing costs, and depreciation costs. The budget prepared by PT. Perkebunan Nusantara III is not yet perfect enough.

Keywords: Evaluation, Budget, Production

How to Cite: K.H, Shinta. Batu Bara, Beby Mashito. \& Angelia, Nina. (2019). Evaluasi Anggaran Biaya Produksi Pada PT. Perkebunan Nusantara III Di Kota Medan. Jurnal Ilmu Pemerintahan, Administrasi Publik dan Ilmu Komunikasi (JIPIKOM), 1(2) 2019: 145-153,
\end{abstract}

*E-mail: sintakismihana@gmail.com ISSN 2550-1305 (Online)

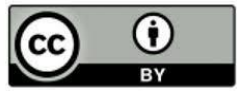




\section{PENDAHULUAN}

Pada hakekatnya perusahaan sangat memerlukan sumber daya untuk mencapai tujuannya, sumber daya merupakan sumber energi, tenaga, kekuatan yang diperlukan untuk menciptakan daya, gerakan, aktivitas, dan tindakan. Sumber daya yang dimaksud antara lain terdiri atas sumber daya alam, sumber daya finansial, sumber daya manusia, sumber daya ilmu pengetahuan, sumber daya teknologi, dan diantara sumber tersebut yang paling penting adalah sumber daya manusia, tanpa adanya sumber daya manusia maka sumber daya lainnya kurang bermanfaat dalam mencapai tujuan organisasi.

Evaluasi sangat dibutuhkan dalam berbagai kegiatan kehidupan manusia seharihari, karena tanpa disadari atau tidak evaluasi sebenarnya sudah dilakukan dengan baik untuk diri sendiri maupun kegiatan lainnya. Evaluasi merupakan proses pengumpulan data untuk menentukan sejauh mana, dalam hal apa dan bagaimana tujuan dari evaluasi tersebut dapat tercapai. Evaluasi merupakan alat untuk menganalisis dan menilai fenomena dan aplikasi ilmu pengetahuan yang baik, evaluasi didukung oleh sejumlah teori, evaluasi biasanya ditunjukan untuk menilai sejauh mana keefektifan kebijakan guna dipertanggung jawabkan kepada yang berwenang demi kesenjangan antara ekspektasi dengan kenyataannya.

Anggaran merupakan perencanaan dari seluruh kegiatan perusahaan yang mencakup berbagai kegiatan operasional yang saling berkaitan dan saling mempenggaruhi satu sama lain untuk mencapai tujuan dan sasaran perusahaan. Anggaran adalah suatu rencana yang terperinci dan dinyatakan secara formal dalam ukuran kualititatif, biasanya dinyatakan dalam satuan uang, untuk memperoleh dan anggunan sumber-sumber suatu organisasi dalam jangka waktu tertentu, biasanya satu tahunan.

Salah satu dari anggaran bagi perusahaan yaitu biaya produksi yang di dalamnya terdapat biaya produksi, biaya produksi biasanya terdiri dari biaya bahan baku, biaya tenaga kerja, dan biaya overhead pabrik, dimana biaya-biaya tersebut saling berhubungan. Adanya perbandingan antara hasil realisasi biaya produksi dengan anggaran biaya produksi yang sudah dianggarkan oleh perusahaan dan dapat digunakan untuk mengevaluasi apakah telah terjadi pernyimpangan baik bagi perusahaan, merugikan maupun yang mengguntungkan.

PT. Perkebunan Nusantara III merupakan perusahaan yang berbentuk BUMN (pemerintah) yang mempunyai peranan penting di masyarakat. PT. Perkebunan Nusantara III juga belum memisahkan antara biaya produksi dan non-produksi hal ini karena mengakibatkan tingginya biaya produksi operasional, PT. Perkebunan Nusantara III juga belum memisahkan biaya bahan baku, biaya tenaga kerja, dan biaya overhead pabrik. Tujuan penelitian mengenai yaitu untuk mengevaluasi anggaran biaya produksi pada PT. Perkebunan Nusantara III. Dalam proses penelitian, peneliti melihat baik atau buruk kinerja yang dilakukan PT. Perkebunan Nusantara III dalam mengevaluasi keseluruhan dari biaya produksi, dan melihat apa yang menjadi permasalahannya.

Menurut Erdogan, Birrin (2002) mengatakan evaluasi adalah mengacu pada keseluruhan prosedur, yang mencakup penetapan standar kerja, perilaku para penilai ketika melakukan penilaian selama periode penilaian kinerja, menentukan peringkat, dan pengomunikasian peringkat tersebut kepada penilaian. Adapun indikator dari hasil penilaian evaluasi dari sebuah program adalah suksesnya penurunan frekuensi dengan demikian, jumlah jam kerja yang sering digunakan dalam evaluasi. Evalausi adalah program suatu proses yang sistematik untuk menentukan suatu penilaian pekerjaan atau pegawai dengan metode dan teknik yang digunakan. 
Menurut Ellen Chistina (2002) anggaran merupakan suatu rrencana yang disusun secara sistematis dalam bentuk angka dan dinyatakan dalam unit moneter yang meliputi seluruh kegiatan perusahaan dalam jangka waktu panjang dan untuk dimasa yang akan datang, oleh karena itu rencana-rencana yang disusun dinyatakan dalam bentuk unit moneter. Anggaran sering disebut dengan rencana keuangan, dalam anggaran satuan kegiatan dan satuan uang yang menempati posisi penting dalam arti segala kegiatan dapat di kualifikasikan dalam satuan uang, sehingga dapat diukur pencapaian yang efesien dan efektivitas dari kegiatan yang dilakukan.

Menurut Sutrisno (2001) biaya produksi adalah biaya yang dikeluarkan untuk mengolah bahan baku menjadi produk selesai. Selanjutnya Hamanto dan Zulkifli (2003) mengatakan bahwa: "Biaya produksi adalah biaya yang dikeluarkan untuk mengolah bahan baku menjadi produk jadi”. Biaya produksi menentukan harga pokok yang melekat pada produk yang dihasilkan perusahaan. Selama suatu produk masih belum terjual maka pembebanan biaya tersebut dalam periode tertentu akan tertunda dan diperlukan sebagai aktiva dalam bentuk persediaan.

\section{METODE PENELITIAN}

Penelitian ini merupakan penelitian yang menggunakan pendekatan kualitatif dengan metode deskriptif yang dimaksud adalah dengan menggunakan keterangan data yang didapat pada saat penelitian dan dari lapangan berupa data yang secara tertulis maupun lisan dari pihak-pihak yang terlibat. Penelitian kualitatif adalah penelitian yang simpel serta sumber datanya belum mantap untuk di rinci, masih fleksibel sehingga memungkinkan terjadinya perubahan. Penelitian ini berjudul " Evaluasi Anggaran Biaya Produksi Pada PT. Perkebunan Nusantara III ."

Sugiyono (2012) metode penelitian Kualitatif biasanya dinamakan sebagai metode baru, karena popularitasnya belum lama, yaitu dimana metode ini dinamakan metode postpositivistik yang berlandaskan pada filsafat postpositivisme. Dalam penelitian kualitatif, adapun pengumpulan data yang dilakukan pada natural setting (kondisi yang ilmiah) sumber data primer dan teknik pengumpulan data lebih banyak dari pada observasi yang berperan serta, wawancara mendalam, dan dokumentasi. Untuk memperoleh data dari lapangan, peneliti mengunakan beberapa metode pengumpulan data sesuai dengan jenis penelitian

Sugiyono (2012) bahwa analisis data adalah proses mencari dan menyusun data secara sistematis dari data yang diperoleh dari hasil wawancara. Catatan yang didapat dari lapangan dan dokumentasi, dengan cara mengorganisasikan data kedalam kategori, yang menjabarkan kedalam unit-unit yang dilakukan, menyusun kedalam pola, memilih mana yang penting dan yang telah dipelajari, serta membuat kesimpulan sehingga lebih muda dipahami oleh diri sendiri maupun untuk orang lain. Analisis data yang digunakan dalam penelitian ini adalah analisis kualitatif. Menurut Miles dan Hubermen (2012) meliputi:

Menurut sugiyono (2012) pengumpulan data berarti merangkum, memilih hal-hal yang yang memfokuskan pada hal-hal yang penting, mencari tema dan polanya, sehingga data yang dikumpulkan akan memberikan gambaran yang lebih jelas dan lebih mudakan peneliti untuk pengumpulan data.

Reduksi data diartikan sebagai proses pemulihan, pemusatan perhatian pada penyederhanaan, pengabstrakan dan transformasi data kasar yang muncul dari catatan tertulis dilapangan selama meneliti untuk memilih informasi yang mana dianggap yang menjadi pusat penelitian lapangan. 
Penyajian data yaitu sebagai kumpulan informasi tersusun yang memberikan kemungkinan adanya penarikan kesimpulan atau pengambilan tindakan. Pengambilan data ini membantu penulis memahami peristiwa yang terjadi dan mengarah pada analisa dan tindakan lebih lanjut berdasarkan pemahaman.

Setelah data disajikan maka dilakukan kesimpulan data atau vertifikasi. Dalam pengambilan keputusan atau vertifikasi membuat kesimpulan sementara dari semula belum jelas menjadi lebih terperinci dengan cara diverifikasi dalam arti meninjau catatan-catatan dengan maksud data yang diperoleh tidak valid untuk memperoleh jawaban atas masalah yang diangkat dalam penelitian.

\section{HASIL DAN PEMBAHASAN}

Penelitian ini dibuat berdasarkan teori Suchman yaitu tentang evaluasi adalah suatu proses penentuan hasil yang telah dicapai dalam beberapa kegiatan yang direncanakan untuk mendukung tercapainya tujuan. Anggaran biaya produksi merupakan biaya-biaya yang terjadi untuk pengolahan bahan baku menjadi produk jadi atau setengah jadi,dalam anggaran biaya produksi terdiri dari biaya bahan baku, biaya tenaga kerja, dan biaya overhead pabrik. Kemudian terjadinya proses penyusunan dengan melakukan Evaluasi tehadap penyimpangan atau selisih biaya anggaran dengan realisasinya. Tujuan dengan dibuatnya Evaluasi adalah untuk mengetahui apa penyebab terjadinya penyimpangan dan bagaimana cara memperbaikin untuk proses penyusunan anggaran biaya produksi selanjutnya.

Perusahaan juga sudah menentukan batas selisih anggaran dengan realisasinya sebesar $10 \%$ baik selisih positif maupun negatif, karena perusahaan memaklumi bahwa anggaran tidak pernah sama dengan nilainya dan realisasi nya senilai $10 \%$ baik untuk selisih positif dan negatif. Adapun indikator dari hasil penilaian evaluasi dari sebuah program adalah suksesnya penurunan frekuensi dengan demikian, jumlah jam kerja yang sering digunakan dalam evaluasi. Evalausi adalah program suatu proses yang sistematik untuk menentukan suatu penilaian pekerjaan atau pegawai dengan metode dan teknik yang digunakan. Adapun Penelitian ini menggunakan Teori Suchman berdasarkan indikator dari teori Edward A yaitu:

\section{Efektifitas}

yaitu yang berkenaan dengan suatu alternatif yang mencapai hasil sesuai dengan yang diharapkan atau ingin mencapai tujuan dari diadakannya tindakan, artinya seberapa baik suatu pekerjaan yang dilakukan maka sejauh mana orang akan menghasilkan target yang sesuai dengan harapan dari pekerja yang dapat diselesaikan sesuai dengan perencanaan baik dalam waktu, biaya, maupun mutu yang dapat dikatakan Efektifitas.

Sesuai dengan tujuan penelitian dalam membuat evaluasi anggaran biaya produksi pada PT. Perkebunan Nusantara III maka dalam mengevaluasi anggaran biaya produksi, peneliti ingin mengetahui sudah efektifkah biaya yang dikeluarkan oleh bagian keuangan untuk memenuhi kebutuhan perusahaan dalam mencapai tujuan dengan diadakannya tindakan.

Biaya merupakan faktor yang sangat berpenggaruh pada kelangsungan suatu usaha, serta upaya pasti dilakukan oleh perusahaan untuk menjaga dan meningkatkan optimalisasi laba dari kegiatan produksi ini yaitu adanya target yang efektif untuk meningkatkan setiap penggeluaran secara efesien dalam mengatur keuangan dalam proses produksi agar perusahaan bertahan untuk dimasa sekarang dan dimasa yang akan datang. Menurut Iwan Kurniawan tentang evaluasi anggaran biaya produksi yang mengalami masalah tentang selisih biaya yaitu:n "Evaluasi merupakan tahap akhir dari proses penentuan hasil yang dicapai dalam kegiatan yang direncanakan untuk mendukung adanya tujuan, namun setiap rencana pastinya ada yang tidak sesuai dengan harapan, terutama pada masalah biaya pastinya akan adanya selisih boaya produksi tersebut dan biasanya timbul karena adanya 
perbedaan biaya produksi yang sesungguhnya terjadi dibandingkan dengan biaya standar, dan biasanya penyebab selisih tersebut yaitu : biaya panen, biaya pemeliharaan, biaya overhead pabrik, biaya penggolahan, biaya penyusutan sehingga harga pokok produksi dan penjualan tidak berjalan efektif."

Biaya didalam perusahaan manufaktur dikelompokkan menjadi beberapa kelompok menurut spesifikasi kegunaannya yaitu:

a. Biaya bahan baku adalah biaya yang dikeluarkan untuk membeli bahan baku yang telah digunakan untuk menghasilkan suatu produk jadi tertentu. Misalnya harga beli kain per potong pakaian, harga beli dari kayu per unit meja, dsb.

b. Biaya tenaga kerja langsung adalah biaya yang dikeluarkan untuk membayar pekerja yang terlibat secara langsung dalam prose produksi. Misalnya tukang jahit di dalam perusahaan garmen, tukang kayu di dalam perusahaan mebel, dll.

c. Biaya Overhead adalah biaya-biaya selain biaya bahan baku langsung dan biaya tenaga kerja langsung tetapi juga tetap dibutuhkan dalam proses produksi.

2. Efesiensi

Yaitu berkenaan dengan jumlah usaha yang diperlukan untuk meningkatkan tingkat efektifitas artinya adanya ukuran yang diperlukan dengan membandingkan rencana penggunaan yang sebenarnya. Untuk melihat tingkat dari pencapaian yang efesiensi maka biasanya biaya produksi dalam perusahaan selalu dalam pencapaian yang efektif setiap tahunnya. Dengan hasil produksi yang maksimal dan sistem periode tertentu dapat dihasilkannya produk dengan program yang telah dibuat. Biasanya dapat disimpulkan bahwa anggaran adalah suatu rencana yang terperinci yang dinyatakan formal dalam ukuran jangka waktu yang panjang ataupun jangka waktu yang pendek sesuai dengan yang ditetapkan perusahaan dari setiap tahap persiapan yang sebelum dimulainya penyusunan rencana dan pengevaluasian dari hasil perencanaan tersebut.

Untuk melihat tingkat dari pencapaian yang efesiensi maka biasanya biaya produksi dalam perusahaan selalu dalam pencapaian yang efektif setiap tahunnya. Dengan hasil produksi yang maksimal dan sistem periode tertentu dapat dihasilkannya produk dengan program yang telah dibuat. Biasanya dapat disimpulkan bahwa anggaran adalah suatu rencana yang terperinci yang dinyatakan formal dalam ukuran jangka waktu yang panjang ataupun jangka waktu yang pendek sesuai dengan yang ditetapkan perusahaan dari setiap tahap persiapan yang sebelum dimulainya penyusunan rencana dan pengevaluasian dari hasil perencanaan tersebut. sedangkan menurut Muhammad Rizal tentang evaluasi yang berjalan efesiensi yaitu: "Selaku orang yang terlibat langsung dalam peroses peningkatan mutu dari penghasilan yang didapat saya hanya melihat seberapa besar luas areal kebun yang dapat menghasilkan, kemudian lebih meningkatkan tenaga kerja, dan norma standar dari pemeliharaan biaya tersebut serta pendapatan produksi setahun nya berjalan efektif."

Berdasarkan efesiensi maka dapat disimpulkan bahwa efesiensi merupakan suatu ukuran yang menyatakan seberapa jauh target (kuantitas, kualitas, dan waktu) yang telah dicapai oleh perusahaan, yang dimana target tersebut sudah ditentukan terlebih dahulu dan membuat program untuk berjalannya kebutuhan yang diinginkan sesuai dengan keefektifan perusahaan.

3. Kecukupan / ketepatan

Yaitu seberapa jauh tingkat efektifitas dalam memuaskan kebutuhan, nilai, atau kesempatan yang menimbulkan adanya masalah. Untuk membuat anggaran biaya produksi biasanya tujuannya agar proses produksi dapat berjalan dengan lancar sehingga perusahaan dapat menghasilkan produk yang tepat waktu, biaya dapat disesuaikan seefesien mungkin.

Dengan adanya kecukupan dalam proses penyusunan anggaran ini akan menimbulkan partisifasi bagi para karyawan untuk mencapai tujuan yang diinginkan agar anggaran tersebut berkomitmen terhadap perusahaan dan para pelaksana anggaran. Menurut Muhammad Rizal 
mengenai kecukupan/ ketepatan dalam menyusun anggaran yaitu: "Memberikan kepuasan kepada konsumen, dan biasanya dibandingkan tahun yang lalu seperti harga pokok produksi dikendalikan serta adanya peningkatan sheet produksi, memperbanyak sheet atau bahan pekat (mentah) maka para konsumen akan merasa senang dan puas."

Dengan memberikan kepuasan terhadap para konsumen maka penghasilan perusahaan akan meningkat, tidak menutup kemungkinan anggara yang ada di PT. Perkebunan Nusantara III pastinya akan bertambah. Kepuasan adalah suatu kondisi dimana keinginan, harapan dipenuhi. Setiap layanan yang diberikan di nilai memuaskan apabila layanan tersebut dapat memenuhi keinginan seseorang. Pengukuran kepuasan merupakan elemen penting dalam menyediakan layanan yang lebih baik, lebih efisien dan lebih efektif.

\section{Pemerantaan}

Pemerataan yaitu secara dekat yang berhubungan dengan rasionalitas subtantive, karena pertanyaan tentang ketepatan kebijakan tidak berkenaan dengan satuan kreteria individu tetapi dua atau lebih kareteria secara bersama-sama. Menurut Iwan kurniawan masalah yang sering terjadi yang mencakup anggaran biaya produksi yaitu: "Perusahaan dalam menangani masalah yang dialami oleh masyarakat, apa lagi mengenai biaya, biasanya kami membuat kebijakan seperti: harga promosi, tenaga kerja pemborong dikurangi."

Masih menurut Menurut Iwan kurniawan, menyatakan bahwa: "Masalah-masalah yang sering mencakup perencanaan didalam anggaran yaitu: perubahan sistem sadap (D3, D4, D5) kemudian ketersediaan tenaga kerja dan komposisi biaya tersedia."

Pemerataan produksi dalam masyarakat akan menentukan pola distribusi pendapatan masyarakat. Sebab dari itu tidak meratanya distribusi pendapatan, dan dengan demikian distribusi barang dan jasa hasil produksi nasional adalah tidak meratanya kepemilikan faktorfaktor produksi. Perbedaan kepemilikan faktor-faktor produksi pada dasarnya adalah suatu hal yang alamiah dan wajar karena adanya perbedaan kualitas manusiawi, perbedaan kesempatan dan karena adanya berbagai hal yang berada di luar kendali manusia yang menempatkan masing-masing orang pada situasi yang berbeda-beda.

\section{Responsibilitas}

Yaitu berkenaan dengan seberapa jauh suatu kebijakan dapat memuaskan kebutuhan secara prefensi, nilai ataupun kelompok. Anggaran biaya tenaga kerja yaitu realisasi biaya yang dikeluarkan oleh perusahaan dalam proses produksi, digunakan berdasarkan data perhitungan anggaran biaya tenaga kerja langsung bahwa standar jam kerja normal adalah 300 hari pertahun. Menurut Iwan Kurniawan dalam menyusun anggaran biaya produksi dalam menanggulangi permintaan konsumen menyatakan: "Dengan adanya Norma tenaga kerja maka sistem sadap selama D3, D4,D5 maka dapat memaksimalkan stabilitas dalam menanggulangi permintaan konsumen dengan cara pada saat hari kerja selama 300 hari dan menambah tarif kerja perharinya sebesar Rp. 200.000."

Data diperoleh peneliti kembali melalui wawancara dengan Irwanto, mengatakan: "Permasalahan yang sering terjadi yaitu mengenai biaya panen yang tidak sesuai, biaya penggolaha, dan penyusutan makin bertambah sehingga menyebab kan terjadinya perselisihan pada saat pembukuan."

Biaya-biaya yang dimiliki perusahaan manufaktur tersebut di atas tidak digabungkan menjadi satu kelompok biaya. Kelima jenis biaya tersebut diatas dikelompokkan lagi kedalam 2 kelompok besar biaya. Pengelompokan tersebut berguna untuk memilih dengan jelas, biayabiaya yang terakumulasi dan membentuk suatu produk dan biaya-biaya berkaitan dengan aktivitas operasional. Biaya-biaya tersebut dikelompokkan ke dalam dua kelompok besar, yaitu:

1. Biaya Produksi:

a. Biaya Bahan Baku Langsung;

b. Biaya Tenaga Kerja Langsung; 
c. Biaya Overhead Gabungan dari biaya bahan baku langsung, biaya tenaga kerja langsung dan biaya overhead pabrik membentuk biaya produksi. Itu berarti biaya produksi adalah keseluruhan biaya yang dikeluarkan perusahaan untuk menghasilkan sejumlah produk yang siap dijual.

2. Biaya Operasional/Komersial :

a. Biaya Pemasaran

b. Biaya Administrasi dan Umum Penjumlahan dari biaya pemasaran dan biaya administrasi membentuk biaya operasi dan biaya komersial. Biaya operasi merupakan komponen biaya perusahaan diluar biaya produksi. Biaya operasi ini merupakan biaya untuk memasarkan produk perusahaan hingga sampai ke tangan konsumen beserta keseluruhan biaya yang dikeluarkan berkaitan dengan proses administratif yang dilakukan perusahaan.

Manfaat Laporan Realisasi Biaya. Laporan realisasi anggaran biaya menyediakan informasi mengenai realisasi pendapatan, belanja, surplus/defisit, dan pembiayaan dari suatu entitas laporan yang masing-masing dibandingkan dengan anggarannya. Informasi tersebut berguna bagi para pelaporan dalam mengevaluasi keputusan mengenai aloksi sumber-sumber biaya.

Hasil produksi dan pemasaran. Hasil produksi PT. Perkebunan Nusantara III terdiri dari dua bagian yaitu: Devisi tanaman tahunan, adalah bagian yang menangani tanaman yang jarak antara tanaman awal dengan masa panen awal lebih dari satu musim atau lebih dari satu tahun. Devisi tanaman semusiman, adalah bagian yang menangani tanaman yang berproduksi hanya satu kali pada setiap musim tanam. Biaya Pemasaran digunakan untuk menampung keseluruhan biaya yang dikeluarkan perusahaan untuk mendistribusikan barang dagangannya hingga sampai ke tangan pelanggan. Biaya ini mencakup: Gaji wiraniaga, komisi wiraniaga, biaya iklan, dan sebagainya. Pengertian Pemasaran adalah suatu kegiatan menyeluruh, terpadu, dan terencana, yang dilakukan oleh sebuah organisasi atau institusi dalam melakukan usaha agar mampu mengakomodir permintaan pasar dengan cara menciptakan produk bernilai jual, menentukan harga, mengkomunikasikan, menyampaikan, dan saling bertukar tawaran yang bernilai bagi konsumen, klien, mitra, dan masyarakat umum.

Proses penyusunan anggaran biaya produksi. Proses penyusunan anggaran merupakan proses penyusunan kerja dengan jangka panjang atau jangka pendek dalam perusahaan yang berorentasi laba. Oleh karena itu, proses penyusunan anggaran sering terjadi karena laba penghasilan tidak sesuai. Sedangkan penggunaan anggaran sebagai kebutuhan untuk kegiatan didalam organisasi. Sebelum perusahaan menyusun anggaran menurut penulis proses penyusunan anggaran yang baik itu adalah dengan menggunakan sistem bottom-up approach yaitu perusahaan mengikuti proses pembukuan dari yang tertinggi hingga yang terendah. Tafsiran produksi biasanya anggaran produksi ini merupakan dasar dalam mempersiapkan anggaran biaya produksi yang terdiri dari:

1. Penyusunan anggaran bahan baku langsung;

2. Penyusunan anggaran biaya tenaga kerja langsung;

3. Penyusunan anggaran biaya overhead pabrik.

Untuk mencapai suatu tujuan perusahaan, penyusunan anggaran sebaiknya harus melibatkan seluruh bagian-bagian yang terkait di dalam perusahaan. Dengan adanya pihak lain maka diharapkan anggaran yang telah disusun akan memperoleh dukungan penuh terhadap seluruh bagian yang ada dan akhirnya masing-masing dari bagian lebih memahami pekerjaannya, dan yang menjadi tujuan perusahaan dapat tercapai. Berikut ini merupakan prosedur penyusunan anggaran yang dilakukan oleh PT. Perkebunan Nusantara III di Kota Medan: prosedur penyusunan anggaran pada PT. Perkebunan Nusantara III dimulai dengan 
diadakannya pertemuan terhadap direktur utama, general manajer, kepala tata usaha, dan asisten dari semua bagian. Dalam setiap pertemuan direktur akan menjelaskan tujuan untuk dimasa yang akan datang, dan direktu utama juga memberikan kesempatan kepada lainnya untuk memberikan usulan anggaran. PT. Perkebunan Nusantara III membuat sistem anggaran nya dengan menggunakan sistem bottom-up yaitu penyusunan anggaran yang dilakukan dari bagian terendah sampai yang tertinggi.

Sebagaimana yang telah dijelaskan bahwa anggaran biaya produksi dilakukan oleh asisten dari setiap bagian pada perusahaan. jika dari setiap usulan adanya koreksi langsung dilaporkan oleh pihak manajer dari bagian tersebut. dari prosedur penyusunan anggaran yang dilakukan telah dijelaskan bahwa setiap yang diperlihatkan oleh perusahaan sudah mengikutisertakan yang ada didalam organisasi. Perusahaan juga sudah menetapkan sistem bottom-up karena mereka lebih mengetahui yang dibutuhkan serta sasaran yang ingin dicapai.

\section{SIMPULAN}

Berdasarkan bab pembahasan hasil penelitian di lapangan yang telah di kemukakan oleh penulis maka saya menarik kesimpulan bahwa PT. Perkebunan Nusantara III telah membuat anggaran biaya produksi dengan periode pertahunnya. PT. Perkebunan Nusantara III telah mengevaluasi perhitungan biaya produksi secara periodik, berdasarkan dengan laporan berdasarkan harga produksi, Harga Jual, dan Rugi Laba dengan menentukan biaya panen, biaya pemeliharaan, biaya overhead pabrik, biaya penggolahan, dan biaya penyusutan. Anggaran yang disusun oleh PT. Perkebunan Nusantara III belum cukup sempurna dikarenakan masih banyaknya terjadi penyimpangan yang signifikan baik penyimpangan yang mengguntungkan maupun yang merugikan. Hal ini menjadi tanggung jawab manajer agar melakukan evaluasi lebih mendalam membuat realisasi biaya agar tidak terjadinya penyimpangan terlalu jauh.

\section{DAFTAR PUSTAKA}

Amrine, H.T, (2010), manajemen dan organisasi produksi, terjemahan, penerbit Erlangga, Jakarta.

Winarno, B, (2008), Kebijakan Publik, salemba empat, Jakarta.

Christina, E. et al, (2002). Anggaran perusahaan suatu pendekatan praktis, Jakarta: PT. Gremedia Pustaka Utama

Darsono, (2000), Anggaran Perusahaan, Teknik Mengetahui dan memahami penyajian Anggaran Perusahaan sebagai pedoman pelaksanaan dan pengendalian aktivitas bisnis, mitra wacana media, Jakarta.

Kadarisman, (2012), Manajemen Sumber Daya Manusia, Terjemahan, PT. Raja Grafindo Persada, Jakarta.

https://www.academia.edu//Evaluasi_penentuan_harga pokok_produksi_PT_Perkebunan_Nusantara_IX_Persero_Surakarta_tugas akhir

https://www.academia.edu/12145798/teori_evaluasi_dalam pendidikan

Lusianus, Y.A, (2007), Evaluasi Anggaran Sebagai Alat Pengendalian Biaya Produksi.

Mathis, R.J. (2012), Manajemen Sumber Daya Manusia, Salemba Empat, Jakarta.

Mulyadi, (2012). akuntansi biaya, Yogyakarta: UPP STIM YKPM,

Munandar, M, (2001). Budgeting: perencanaan kerja pengkoordinasian kerja pengawasan kerja, Yogyakarta: BPFE-Yogyakarta,

SinaMbela, L.P. Manajemen Sumber Daya Manusia, Jakarta.

Renny, W, (2003), Evaluasi Penentuan Harga Pokok Produksi PT. Perkebunan Nusantara IX Surakarta, Jurnal Ilmu Pendidikan. Online.

Devi, S.Y. (2010). Analisis Anggaran Biaya Produksi Sebagai Alat Perencanaan dan Pengawasan, Skripsi, Fakultas ekonomi dan Ilmu sosial UIN Sultan Syaif Kasim Pekanbaru Riau.

Sugiyono, (2012), Memahami Penelitian kualitatif, alfabeta, Bandung.

Witjaksono, A, (2000). Akuntansi biaya akarta: PT. Raja Grafindo Persada, 